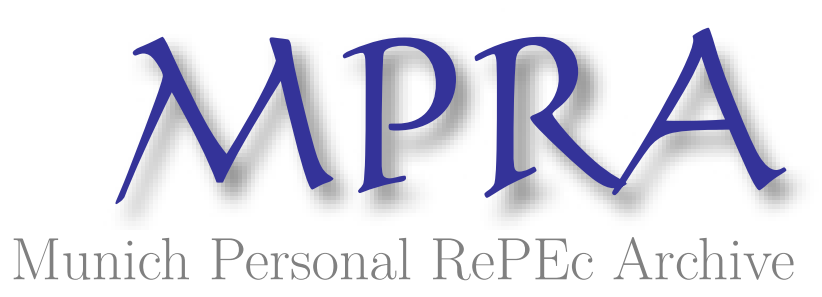

On the causal nature between financial development and economic growth in the Democratic Republic of the Congo: Is it supply leading or demand following?

PINSHI, Christian P.

University of Kinshasa

10 July 2020

Online at https://mpra.ub.uni-muenchen.de/101837/

MPRA Paper No. 101837, posted 15 Jul 2020 09:27 UTC 


\title{
On the causal nature between financial development and economic growth in the Democratic Republic of the Congo: Is it supply leading or demand following?
}

\author{
Christian P. Pinshi ${ }^{1}$ \\ ${ }^{1}$ University of Kinshasa \\ Christian.pinshi@unikin.ac.cd \\ ORCID: https:// orcid.org/0000-0002-9618-5542
}

\begin{abstract}
This paper seeks to study and answer the question on the nature and direction of the causality between financial development and economic growth in the Democratic Republic of the Congo (DRC) using data from 2004 to 2019. The long-term relationship not being robust, we opted for the short-term dynamics with the causality test in the sense of Granger to support this question. The results indicated the existence of a one-way causality from economic growth to financial development. This result is in line with the Demand following hypothesis, given the country's economic and financial landscape, which presents a less deep financial system. Consequently, choices of growth policies (increase in knowledge, infrastructure, pleasant business climate, structural reforms, etc.) should be adopted to enhance and develop the Congolese financial system. However, we recognize that once growth is restored and becomes sustainable, financial development could lead to sustained and resilient economic growth.
\end{abstract}

Keywords : Economic growth, financial development

JEL Code :O16, O38, O44, E44, G20, C32 


\section{INTRODUCTION}

The nature and direction of causality between the financial system and economic growth has attracted wide attention in the past 30 years, and many studies focused in this area have highlighted the development of the financial system, thus that, according to some authors, financial development has become a weapon to boost economic growth (Bagehot, 1873; Schumpeter, 1911; Calderon, 2003; Levine, 2005; Demirgüç-Kunt and Levine, 2008). Various points of view are highlighted, through various previous works, on the way in which financial development is linked to economic growth (Goldsmith, 1969; McKinnon, 1973; Shaw, 1973; King and Levine, 1993; De Gregoria and Guidotti, 1995). It started with Schumpeter (1911), who argued that financial development plays a role in economic growth. King and Levine (1993) supported Schumpeter's work by showing that financial development is strongly linked to economic growth and has a positive and significant effect on it. At the same time, other studies (Robinson, 1952; Gurley and Shaw, 1967; Lucas, 1988; Chandavarkar, 1992) have highlighted the weakness of this relationship and have shown that financial development is not a driving agent. to support sustainable economic growth. The causal link between financial development and economic growth is divided into four categories. The first is the vision of Supply leading, which means that financial development is a factor driving the promotion of economic growth, hence financial development causes economic growth. Second, the Demand following, which indicates that economic growth is the factor driving financial development, hence, economic growth causes the development of the financial sector. A third type of relationship looks at the mutuality and reciprocity of the direction of the relationship between financial development and economic growth, hence the two-way causality between financial development and economic growth. The fourth type of relationship is subject to noncausality between financial development and economic growth.

These different views on the nature of the causality between financial development and economic growth, pushes us to conduct a study to verify the direction of this relationship in the Democratic Republic of Congo (DRC), so that, knowledge direction of causality has implications for the country's economic policy. In addition, for more than a decade, we have observed the economic dynamics in which the DRC finds itself, which experienced a period of major crises around the 1990s which recovered in 2002. Consequently, apart from the tones of the shocks from the financial crisis of premiums in 2008, the fall in commodity prices in 2015 and the current crisis of COVID-19, economic growth has always evolved on average by $5 \%$. The same dynamic is observed for the financial system, which has experienced a fairly remarkable quantitative expansion since the early 2000s. However, with a modest and undeveloped articulation (Pinshi, 2017a), the Congolese financial system remains more limited by and relation to other African countries and in the world (Ilunga and Pinshi, 2018). Although in turbulence and in its infancy, the financial system has grown over time (Figure 1). The ratio of bank credit to the private sector to GDP and the ratio of broad money to GDP reflect this temporal development since the 2000s combined with an increase, although very modest in financial service (Figure 2). This quantified progression of the financial system is far from the level of financial development expected, because the size of the financial sector is still embryonic and very low, with a ratio of broad money to GDP still evolving below $15 \%$ and a ratio of financial depth scalable below $10 \%$.

The question on the casual nature is relevant since the pursuit of sustainable economic growth and financial development have become important items on the agenda to revitalize the Congolese economy towards virtuous prosperity. The obligation arises from the need to understand the economic functioning of the country on the wheels of financing sustainable economic growth and to establish a developed financial system, as it turns out it turns out that the Congolese financial sector is relatively limited and slow to direct resources to economic activity. This is why it is important to study the nature of the causal link between financial development and economic 
growth in the DRC, because of the result can clarify the character and facilitate the direction to take for macroeconomic policies.

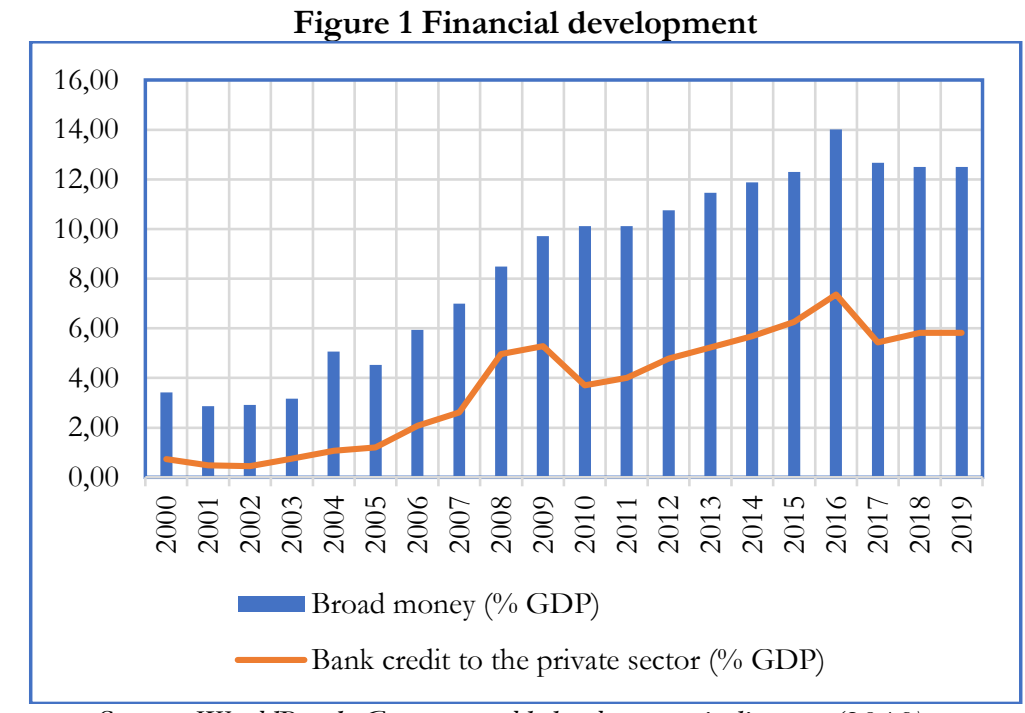

Source: WorldBank Group, world-development-indicators (2019)

Figure 2. Financial service

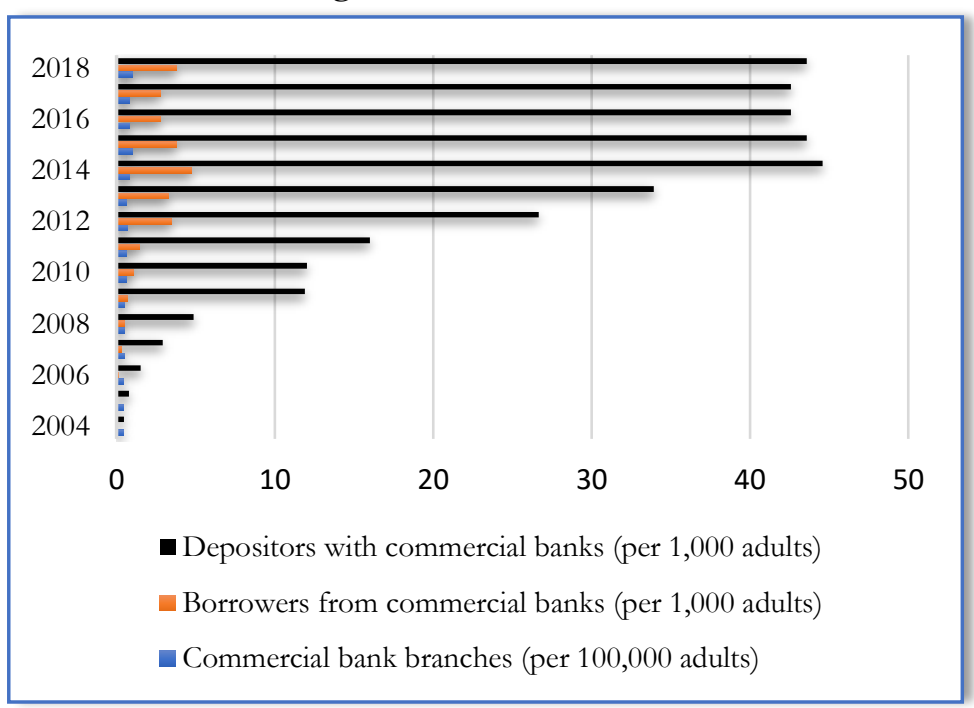

Source: WorldBank Group, world-development-indicators (2019)

This first section is followed by a literature review of empirical and theoretical studies on the causal link between financial development and economic growth. The data and methodology used in this paper will be determined in section 3, while section 4 will highlight the empirical results of the analysis. Section 5 will conclude with a conclusion.

\section{LITERATURE REVIEW}

Theoretical predictions recognize that a developed financial system could be an essential means of driving healthy and sustainable growth. From this point of view, an underdeveloped financial sector is an obstacle to economic growth (Gelbarde et al, 2014). The relationship between financial development and economic growth has been the subject of much literature. This section is grouped into four subsections concerning the four categories of nature on the relationship between financial 
development and economic growth. The first will examine the supply leading hypothesis, the second will mention the following demand hypothesis, the third will highlight the possible feedback effect and the last will reject any causation between financial development and economic growth.

\subsection{SUPPLY LEADING: FINANCIAL DEVELOPMENT LEADS ECONOMIC GROWTH}

Several studies have demonstrated the causal effect of financial development on economic growth (Schumpeter, 1911; Goldsmith, 1969; McKinnon, 1973; King and Levine, 1993; Beck and Levine, 2004; Levine, 2005; Demirguc-Kunt, 2006). The Supply Leading hypothesis postulates that financial development plays a major and stimulating role in economic growth. Several channels through which financial development promotes economic growth include the efficient allocation of capital, the mobilization of savings through attractive instruments, the reduction of problems of anti-selection and moral hazard resulting from the information asymmetry. Essentially, a deep financial system supposes that the activities of intermediation of financial institutions or the monetary creation of commercial boats encourage the real sector to increase its production capacity, which subsequently broadens the productive base of the economy (Akinlo and Egbetunde, 2010; Oluitan, 2012). Spears (1992) uses the Broad money to GDP ratio as an indicator to measure financial development in his study of the relationship between financial development and economic growth in ten countries in sub-Saharan Africa. Using Granger's causality test, he concludes that there is strong causality ranging from financial development to economic growth. Berthelemg and Varoudakis (1996) obtain the same results using a large sample of transnational data and conclude that financial development promotes growth by mobilizing savings. Rajan and Zingales (1998) with a multiple regression model, they find that financial development directly influences economic growth. At the same time, Ahmed and Ansari (1998) examined the relationship between financial development and economic growth for India, Pakistan and Sri Lanka. Based on the correlation analysis, of Granger causality, they concluded that the financial system affects and causes growth. Hence to promote economic growth it is necessary to encourage the development of the financial system.

Bhattacharya and Sivasubramanian (2003) test the Supply leading hypothesis in India for the period 1970 to 1999 . Using the error correction model and the causality test, they find that financial development causes economic growth. The same conclusion is drawn from the work of Fase and Abma in 2003, which use the Granger test to show the causal effect of the financial system on economic growth in 9 countries in Asia, Bangladesh, India, Malaysia, Pakistan, Philippines, Singapore, South Korea, Sri Lanka and Thailand. In addition, some developing countries also became the subject of an empirical study by Christopoulos and Tsionas (2004) through which they aimed to examine the relationship of financial depth and long-term economic growth using analysis co-integration of the panels. They found that there is a long-term relationship between these two variables, and that financial depth causes economic growth.

Gries and al., (2009) led Granger's causality methodology to establish the causal relationship between deepening of the economy, trade openness and economic growth in 16 countries in subSaharan Africa. The results supported the Supply leading hypothesis. Likewise, Öztürk and Acaravc1 (2013) used ARDL, VECM and causality in Turkey for the period 1960 to 2007, their results validated the Supply leading hypothesis.

Shittu (2012) and Ndako (2017) examined the impact of the financial system on economic growth in Nigeria. Their results revealed that financial development has a significant impact on economic growth in Nigeria. Altaee and Al-Jafari (2015) studied the relationship between trade openness, 
financial development and economic growth in Bahrain from 1980 to 2012. The VECM model in combination with the causality analysis between the variables. The results show that trade openness and financial development are the engines of economic growth. Thus, the policy adopted by Bahrain should focus on improving the financial sector and increasing trade openness to achieve increasingly strong sustainable economic growth.

Mollaahmetoğlu and Akçalı (2019) examine the relationship between financial development, financial innovation and economic growth using panel data. With a sample covers fifteen countries for the period 2003-2016. They conclude that financial development and financial innovation have a significant impact on economic growth. The same vision is analyzed by Kamalu and al., (2019) on the relationship between financial development and economic growth in Nigeria for the period from 1978 to 2018. Using causality analysis, they conclude that financial development and financial inclusion have a significant impact on economic growth.

In the Democratic Republic of the Congo, there are not many studies on the causal link between financial development and economic growth. The most striking work is that of Lonzo and Kabwe (2015), who studied the effect of financial intermediation on economic growth in the DRC for the period from 2001 to 2012. Their results suggested that financial development had an effect. positive and significant on growth. Likewise Pinshi (2017b) confirmed this causal effect ranging from the financial system to economic growth in the DRC.

\subsection{DEMAND FOLLOWING: ECONOMIC GROWTH DRIVES FINANCIAL DEVELOPMENT}

The Demand following hypothesis assumes that the expansion of economic activity is forcing the real sector to ask for funds from financial institutions to cope with the increase in productivity. As a result, the economy is pushing financial institutions to mediate and create money. According to Lucas (1988), the relationship between financial development and economic growth has long been overestimated in the literature. In this perspective, Robinson (1952), Kuznets (1955), Stern (1989), Singh (1997), Beck and al. (2000), Odhiambo (2008), Nazlıoglu and al. (2009), Ductor and Grechyna (2015) have argued that increased growth generally leads to development of the financial sector.

The works of Kar and Pentecost (2000) have shown, using Granger causality and co-integration, that economic growth increases financial development in Turkey. In addition, Al-Tammam (2005) found that there is a co-integration between financial development and economic growth in Oman, Saudi Arabia and Kuwait, and that the causality ranged from economic growth to financial development in all countries in the short and long term. Ang and McKibbin (2007) conducted a time series analysis from 1960 to 2001 in Malaysia to verify the causal link between financial development and economic growth. Their results verified and validated the following Demand hypothesis.

Further, Odhiambo (2009) studied the causality between finance and economic growth in South Africa for the period 1960-2006. He found that there was only one causality between the economy and the financial sector. The results indicated that financial development plays a minor role in contributing to economic growth. Therefore, he concluded that the Supply leading hypothesis did not hold in South Africa for the period of analysis.

Hasan (2018) examines the relationship between financial development and economic growth in Indonesia. He finds that economic growth has a very significant effect on financial development. Hence the hypothesis of a Demand following is verified. Bist (2018) also studies this relationship 
for the case of African and other low-income countries. Its results are consistent with the Demand following hypothesis.

Ismail and al., (2019), examine the link between financial development and economic growth in Malaysia during the period from 1990 to 2013. By adopting the Johansen cointegration test to verify the existence of a relationship of long term between the variables used and the Granger causality test to determine the direction of the relationship for the variables. Their results highlight a longterm relationship between financial development and economic growth, at the same time, they supported the existence of a causality that goes from economic growth to financial development.

\subsection{FEEDBACK EFFECT: A TWO-WAY CAUSAL RELATIONSHIP BETWEEN FINANCIAL DEVELOPMENT AND ECONOMIC GROWTH}

The defense of two-way causality assumes that financial development and economic growth exert mutual influence. This means that the more the financial system develops, the economic growth is stimulated, which increases the demand for credit due to increased activity. Ultimately, we enter a situation of feedback effect and virtuous circle. One of the pioneering works is that of Lewis (1955) to validate a two-way causality between financial development and economic growth. Several studies have also noted this type of retroactivity and conducted studies that support this assertion. These include Patrick (1966), Wood (1993), Demetriades and Hussein (1996), Greenwood and Bruce (1997), Akinboade (1998), Luintel and Khan (1999), Ghirmay (2004), Shan and Jainhong (2006), Abu-Bader and Abu-Qarn (2008), Akinlo and Egbetunde (2010), Shahbaz and al. (2012) and, Nayak and Yingnan (2019).

Bangake and Eggoh (2011) found the existence of a two-way causality between financial development and economic growth in 71 countries, including 18 developing countries from 1960 to 2004. On the other hand, Kar and al. (2011) conducted a study on MENA countries for the period from 1980 to 2007 . They also found that there is a two-way relationship between financial development and economic growth. Likewise for Hassan and al. (2011), the results of their work advocated a feedback effect between the financial sector and economic growth for most of the emerging regions.

Musamali and al. (2014) examined the relationship between financial development and economic growth in 50 African countries for the period 1980-2008. They have shown a two-way causal link between the financial system and economic growth. Al-Qudah (2017) studied the correlation between financial development and economic growth in Jordan using data for the period 19932014. He also found a two-way causality between financial development and economic growth. The same result on the two-way causality between the financial system and economic growth was found in the work of Okpara and al (2018) using co-integration and causality analysis in Nigeria from 1981 to 2014.

\subsection{CONTROVERSIES: NO CAUSATION RELATIONSHIP}

The studies cited above have confirmed, regardless of the direction of causation, a link between financial development and economic growth. However, other studies have found controversial and / or totally broken relationships between financial system development and economic growth. From this point of view, Deidda and Fattouh (2002), Demetriades and James (2011), Kumar (2011), Soytaş and Küçükkaya (2011), Hsueh, and al. (2013) and Kenza and Mohamed (2015) argue that 
financial development and economic growth are not causally linked and that the role of financial development in economic growth is over-emphasized.

Gupta and Rao (2018) study the causal relationship between financial development and economic growth in BRICS economies. Using the Toda - Yamamoto causality test from 1996 to 2016, they find that there is no consistency in causality between the financial sector and economic growth among the BRICS countries.

The above theoretical and empirical discussions that have sprung up from different and competing views on the causality between financial development and economic growth. In addition, the direction of causality is complex and important, partly because of the economic policy put forward and the interventions linked to structural reforms. It is in this context that it is crucial to examine the relationship of the financial system and economic growth in the case of the DRC.

\section{DATA AND METHODOLOGY}

To examine the question on the nature of the causality between financial development and economic growth, covering the quarterly period from 2004-2019, we isolate the World Development Indicator series (WDI, 2020) from the outlook for world economy (WEO, April 2020) of the International Monetary Fund (IMF). Real GDP is used to measure economic growth. At the same time, three variables which are the ratio of bank credit to the private sector to GDP (CPS), the ratio of money supply to GDP (BM), financial flows (S-I) (difference between national savings and national investment), are used to measure financial development.

The methodology of the vector autoregressive model (VAR) is specified to test the causal nature between financial development and economic growth in the sense of Granger. The augmented Dickey-Fuller unit root tests are calculated for individual series to prove whether the variables are stationary. The Augmented Dickey-Fuller test (ADF) involves the estimation of the following three equations, in our calculation we estimate only one equation:

$\Delta y_{t}=\alpha+\beta t+\vartheta y_{t-1}+\sum_{j=1}^{p-1} \phi_{j} \Delta y_{t-j}+v_{t}$

Where $v_{t}$ is the residue, $p$ is the offset chosen according to the Bayesian information criterion (BIC). The null hypothesis is that $y_{t}=y_{t-1}+v_{t}$ where $v_{t} \approx N I D\left(0, \sigma^{2}\right)$. According to the null hypothesis, $\vartheta$ will be negatively biased in a limited sample, so only one test is necessary to determine $H_{0}: \vartheta=0\left[y_{t} \approx I(1)\right]$ against $H_{1}: \vartheta<0\left[y_{t} \approx I(0)\right]$. This model is less restricted because it takes into account a deterministic trend (Pinshi, 2020; Athanasios and Antonios, 2010).

The methodology developed by Granger allows us to assess whether the causality between financial development and economic growth. We distinguish two variables, economic growth $y_{t}$ and financial development $x_{t}$. The granger causation test (Granger, 1969) assumes that $x_{t}$ causes $y_{t}$ if the forecast of $y_{t}$ based on past information from $x_{t}$ and $y_{t}$ is better than the forecast based only on past information from $y_{t}$. In other words, $x_{t}$ causes $y_{t}$, simply means that $x_{t}$ has predictive power over $y_{t}$.

$x_{t}=\tau_{0}+\sum_{i=1}^{p} \tau_{i} x_{t-i}+\sum_{i=1}^{p} \xi_{i} y_{t-i}+\mathrm{v}_{1 t} \quad \mathrm{t}=1, \ldots, \mathrm{T}$ 
$y_{t}=\eta_{0}+\sum_{i=1}^{p} \eta_{i} y_{t-i}+\sum_{i=1}^{p} \varphi_{i} x_{t-i}+v_{2 t}$

The null hypothesis that $x_{t}$ does not cause $y_{t}$ consists in testing the joint nullity of the parameters : $H_{0}: \xi_{1}=\ldots=\xi_{p}=0$

The null hypothesis that $y_{t}$ does not cause $x_{t}$ consists in testing the joint nullity of the parameters : $H_{0}: \varphi_{1}=\ldots=\varphi_{p}=0$

\section{RESULTS AND DISCUSSIONS}

The results of the Augmented Dickey Fuller test (Chart 1) show a variety of the level of stationarity, GDP and the ratio of bank credit to the private sector to GDP are stationary in second difference, the ratio of broad money to GDP is stationary after the first difference, the financial flow variable is stationary in level. This means that a linear combination of financial development and economic growth has only a small possibility of cointegration, in other words, the long-term relationship between financial development and economic growth in the DRC is not robust.

It is very important to know the lag optimal number, to estimate the direction of causality. The Bayesian information criterion is used to determine the length of the offset. Chart 2 shows a lag of one quarter. With information on the length of the offset, it is now possible to check the causality of our variables. In addition, the Breusch-Godfrey LM serial correlation test (Chart 3) shows that there is no serial correlation and that our model is robust, reliable and good. For more conformity, the stability test (Figure 4) used shows that the model is stable.

The result of causality is summarized in the following graph. The causality is unidirectional, going from economic growth to financial development. This result is consistent with the work of Kar and Pentecost (2000), Odhiambo (2008), Nazlioğlu and al. (2009), Ductor and Grechyna (2015), Hasan (2018), and Ismail and al., (2019).

The result confirms the Demand following hypothesis that economic growth has a significant predictive power over financial development. Although this view is not universal, it is recognized that the growth of economic activity develops the financial system. These results contradict those of Pinshi (2017b) and those of Lonzo and Kabwe (2015) who used a time series from 2001 to 2012 to show that financial intermediation (financial development) influences economic growth in the DRC.

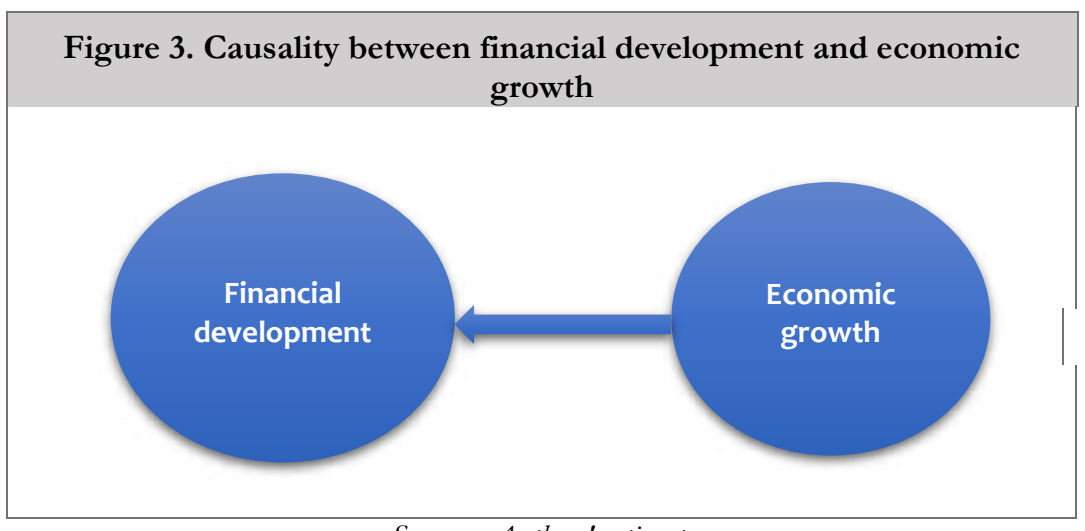

Source: Authors' estimate 
This study highlights the importance of the growth policy that should be adopted in the DRC. From empirical evidence based on the causal effect of economic growth on the development of the financial system, it has been proven by several studies cited above that economic growth is a key factor in deepening the financial system. Therefore, the main policy recommendations and implications are that measures to increase economic growth, such as the accumulation of endogenous factors (knowledge, education, research, training, technology); attracting foreign direct investment; macroeconomic stabilization; far-reaching structural reforms ${ }^{1}$ (Ilunga and Pinshi, 2018; Akitoby and Cinyabuguma, 2004); strengthening infrastructure (transport, telecommunications, water and electricity, building, roads); creating an environment conducive to the development of the private, judicial and regulatory sector; and the promotion of good governance, would be crucial and important for improving financial development in the DRC.

\section{CONCLUSION}

This paper examines the question of the nature of the causality between financial development and economic growth in the DRC using the Granger causality test. Granger's causality test shows a one-way relationship from economic growth to financial development. This result confirms the following Demand hypothesis in the DRC. Therefore, measures such as, the accumulation of national investment, knowledge, education, research, training, technology; attracting foreign direct investment; macroeconomic stabilization; far-reaching structural reforms; strengthening infrastructure; creating an environment conducive to the development of the private, judicial and regulatory sector; and the promotion of good governance, are important to promote economic growth in order to improve financial development in the DRC. However, we recognize that after restoring healthy growth, financial development could be important to drive economic growth, given the non-addition of control variables such as the inflation rate, the exchange rate, the degree of openness and financial inclusion, we are proposing a study for future work that is broad enough to better understand and clarify the nature of causality and the impact of development.

\footnotetext{
${ }^{1}$ See Akitoby, B. and Cinyabuguma, M. (2004) for more details on the economic growth policy in the DRC.
} 


\section{APPENDICES}

Chart 1. Unit root test (Augmented Dickey-Fuller)

\begin{tabular}{|c|c|c|c|}
\hline \multicolumn{2}{|c|}{ Variables } & Trend and Intercept & Integration order \\
\hline CPS & 2nd difference & $-4.761^{*}$ & $\mathrm{I}(2)$ \\
\hline BM & 1st difference & $-3.976^{*}$ & $\mathrm{I}(1)$ \\
\hline S-I & In level & $-5.370^{*}$ & $\mathrm{I}(0)$ \\
\hline GDP & 2nd difference & $-4.949^{*}$ & $\mathrm{I}(2)$ \\
\hline
\end{tabular}

Note: DCP = Bank credit to the private sector / GDP; Dev = Broad money/GDP; S-I = Financial system capital flows (national savings minus national investment) / GDP

Chart 2. Bayesian Information Criterion
\begin{tabular}{|c|c|}
\hline VAR Lag Order Selection Criteria \\
Sample: 2004Q1 2019Q4 \\
Included observations: 42 \\
\hline \multicolumn{2}{|c|}{ Lag } \\
\hline 0 & BIC \\
\hline 1 & 11,165 \\
2 & $7,849 *$ \\
3 & 8,040 \\
4 & 9,043 \\
5 & 9,347 \\
6 & 9,849 \\
\hline
\end{tabular}

\section{Chart 3. Breusch-Godfrey autocorrelation test}

\section{VAR Residual Serial Correlation LM Tests}

Null Hypothesis: no serial correlation at lag order $h$

Sample: 2004Q1 2019Q4

Included observations: 46

\begin{tabular}{|c|cc|}
\hline Lags & LM-Stat & Prob \\
\hline \hline 1 & 13,377 & 0,645 \\
2 & 15,084 & 0,518 \\
3 & 6,032 & 0,987 \\
4 & 51,366 & 0,001 \\
5 & 6,670 & 0,979 \\
6 & 11,781 & 0,758 \\
\hline
\end{tabular}


Figure 4. Stability test

\section{Inverse Roots of AR Characteristic Polynomial}

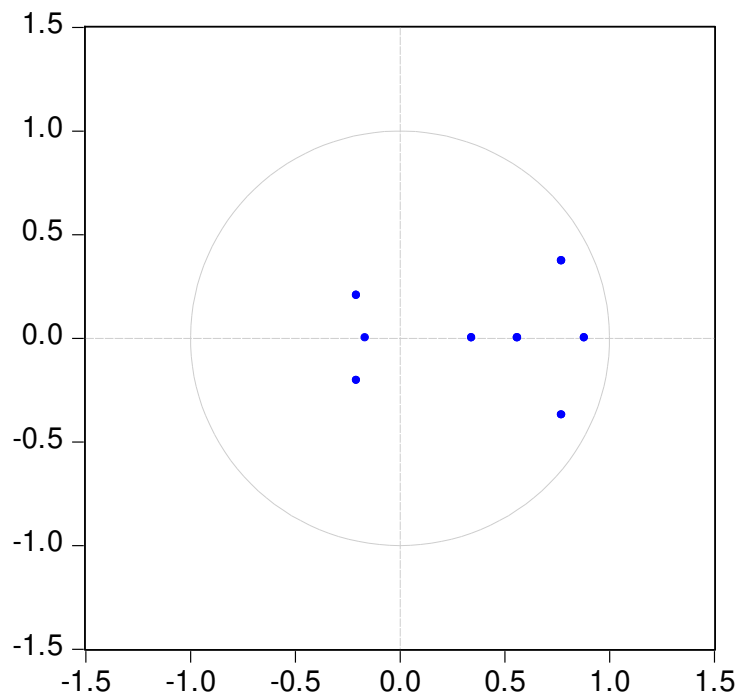

Chart 4. Causality test results

\begin{tabular}{|l|l|l|l|}
\hline \multicolumn{1}{|c|}{ Null hypothesis } & Obs & $\begin{array}{c}\text { F- } \\
\text { Statistic }\end{array}$ & p-value \\
\hline BM does not Granger Cause CPS & 47 & 0.231 & 0.632 \\
CPS does not Granger Cause BM & & 3.480 & 0.068 \\
\hline S-I does not Granger Cause CPS & 61 & 5.003 & 0.029 \\
CPS does not Granger Cause S-I & & 0.772 & 0.383 \\
\hline GDP does not Granger Cause CPS & 61 & 6.045 & 0.016 \\
\hline CPS does not Granger Cause GDP & & 0.299 & 0.586 \\
\hline S-I does not Granger Cause BM & 49 & 1.586 & 0.214 \\
BM does not Granger Cause S-I & & 0.041 & 0.839 \\
\hline GDP does not Granger Cause BM & 48 & 0.024 & 0.876 \\
BM does not Granger Cause GDP & & 0.102 & 0.750 \\
\hline GDP does not Granger Cause S-I & 62 & 0.005 & 0.941 \\
S-I does not Granger Cause GDP & & 1.072 & 0.304 \\
\hline
\end{tabular}

Lags: 1 


\section{REFERENCES}

Abu-Bader, S., and Abu-Qarn, A.S. 2008. Financial development and economic growth: Empirical evidence from six mena countries. Review of Development Economics, vol.12, pp. 803-817.

Ahmed, S.M., and Ansari, M.I. 1998. Financial sector development and economic growth: The South-Asian experience. Journal of Asian Economics, vol. 9. pp. 503-517.

Akinboade, O. A. 1998. Financial development and economic growth in Botswana: a test for causality. Savings and Development, vol.22, pp.331-348.

Akinlo, A. E., and Egbetunde, T. 2010. Financial development and economic growth: The experience of 10 sub-saharan african countries revisited. The review of finance and banking, Vol.02, pp.017-028.

Akitoby, B. and Cinyabuguma, M. 2004. Sources of Growth in the Democratic Republic of the Congo: A Cointegration Approach. International Monetary Fund, IMF Working paper n0.04/114, juillet.

Al-ammam, M. 2005. Causality between financial development and economic growth: The case of Kuwait, Oman, and Saudi Arabia. Colorado State University.

Al-Qudah, A. M. 2017. Financial development and economic growth of Jordan. Research Journal of Finance and Accounting, vol.7, pp.143-152.

Altaee, A. H., and Al-Jafari, K. M. 2015. Financial development, trade openness and economic growth: A trilateral analysis in Bahrain. International Journal Economicsand Finance, vol.7, pp.241-254.

Ang, J.B., and McKibbin, W.J. 2007. Financial liberalization, financial sector development and growth: Evidence from Malaysia. Journal of Development Economics, vol.84, pp. 215-233.

Athanasios, V., and Antonios, A. 2010. Financial development and economic growth: An empirical analysis for France. International Review of Applied Economic Research, vol.5, December.

Bagehot, W. 1873. Lombard Street : A description of money market. Federal Reserve of New York, Homewood, IL: Richard D. Irwin, 1962 edition.

Bangake, C., and Eggoh, J. 2011. Further evidence on finance-growth causality: A panel data analysis. Economic Modelling, vol.35, pp.176-188. https://doi.org/10.1016/j.ecosys.2010.07.001

Bhattacharya, P.C., and Sivasubramanian, M.N. 2003. Financial development and economic growth in India: 1970-1971 to 1998-1999. Applied Financial Economics, vol.13, pp. 925-929.

Beck, T., Levine R., and Norman, L. 2000. Finance and the Sources of Growth. Journal of Financial Economics, Vol.58, pp 261-300.

Beck, T., and Levine, R. 2004. Stock markets, banks, and growth : panel evidence. Journal of Banking and Finance, vol. 28, pp 423-442.

Berthelemg, J.C., and Varoudakis, A. 1996. Financial Development Policy and Growth. OECD. 
Bist, J. P. 2018. Financial development and economic growth: Evidence from a panel of 16 African and non-African low-income countries. Cogent Economics \& Finance, https://doi.org/10.1080/23322039.2018.1449780.

Calderon, C. 2003. The Direction of Causality between Financial Development and Economic Growth. Journal of Development Economics, vol. 72, n 1, pp. 321-334, October.

Chandavarkara, A. 1992. Of Finance and Development: Neglected and Unsettled Questions. World Development, Vol.20, pp.133-142.

Christopoulos, D. K., and Tsionas, E. G. 2004. Financial development and economic growth: Evidence from panel unit root test and cointegration test. Journal of Development Economics, vol.73, pp.55-74. https://doi.org/10.1016/j.jdeveco.2003.03.002

Deidda, L., and Fattouh, B. 2002. Non-linearity between finance and growth. Economics Letters, vol.74, pp.339-343.

De Gregoria, J., and Guidotti, P. E. 1995. Financial development and economic growth. World Development, vol. 23, pp. 433-448, March.

Dematriades P.O., and Hussain, K. A. 1996. Does financial development cause economic growth? Time series evidence from 16 countries. Journal of Development Economics, vol.51, pp. 387 - 411.

Demetriades, P. O., and James, G. A. 2011. Finance and Growth in Africa: The Broken Link. Economic Letters 113.

Demirguc-Kunt, A. 2006. Finance and economic development: Policy choices for developing countries. World Bank Policy Research Working Paper no. 3955.

Demirgüç-kunt, A., and Levine, R. 2008. Finance, Financial Sector Policies and Long-Run Growth. Banque mondiale, Policy Research Working Paper, n0 4469, January.

Ductor, L., and Grechyna, D. 2015. Financial development, real sector, and economic growth. International Review of Economics \& Finance, vol.37, pp.393-405.

Fase, M.M., and Abma, R.C. 2003. Financial environment and economic growth in selected Asian countries. Journal of Asian Economics, vol14, pp. 11-21.

Gelbard, E., Gulde, A.M., and Maino, R. 2014. Développement financier en Afrique subsaharienne : les enjeux pour une croissance soutenue. Revue d'économie financière 2014/4(n0 116), p. 19-42.

Ghirmay, T. 2004. Financial development and economic growth in sub-Saharan African countries: Evidence from time series analysis. African Development Review, vol.16, pp. 415-432.

Goldsmith, R. 1969. Financial Structure and Development. $1^{\mathrm{e}}$ ed. New Haven: Yale University Press.

Granger, C. W. 1969. Investigating causal relations by econometric models and cross-spectral methods. Économetrica, vol. 37, no. 3, pp. 424-438, August. 
Greenwood, J., and Bruce, S. 1997. Financial markets in development, and the development of financial markets. Journal of Economic Dynamic and Control, vol.21, pp.145-181.

Gries. T., Kraft, M., and Meierrieks, D. 2009. Linkages between financial deepening, trade openness, and economic development: Causality evidence from Sub-Saharan Africa. World Development, vol. 37, pp.1849-1860. https://doi.org/10.1016/j.worlddev.2009.05.008.

Gupta S. K., and Rao, R. P. (2018). The causal relationship between financial development and economic growth: an experience with BRICS economies. Journal of Social and Economic Development, vol. 2, n0. 20, DOI 10.1007/s40847-018-0071-5.

Hasan, H. 2818. Relationship between financial development and economic growth: Empirical evidence in Indonesia. International Journal of Economics and Finance, vol. 10, no. 12.

Hassan, M. K., Sanchez, B., and Yu, J. S. 2011. Financial development and economic growth: New evidence from panel data. The Quarterly Review of Economics and Finance, vol.51, pp.88-104. https://doi.org/10.1016/j.qref.2010.09.001.

Hsueh, S. J., Hu, Y. H., and Tu, C. H. 2013. Economic growth and financial development in Asian Countries: A bootstrap panel granger causality analysis. Economic Modelling, vol.32, pp.294-301.

Ilunga, S. K., and Pinshi, C. P. 2018. Quel rôle pour les banques centrales dans la promotion de la croissance économique? MPRA Paper no. 99706.

Ismail, F., Ab-Rahim, R., and Pei-Chin, L. 2019. Nexus Between Financial Development and Economic Growth in Malaysia. International Journal of Academic Research in Business and Social Sciences, vol. 9, no. 1, DOI: 10.6007/IJARBSS/v9-11/5328. January.

Kamalu, K., Wan Ibrahim, W. H., Ahmad, A. U., and Mustapha, U. A. 2019. Causal Link Between Financial Developments, Financial Inclusion and Economic Growth in Nigeria. International Journal of Scientific \& Technology Research, vol.8, December.

Kar, M., and Pentecost, E. J. 2000. Financial Development and Economic Growth in Turkey. Purther Evidence on the Causality Issue, Department of Economics, Loughborough University.

Kar, M., Nazlığlu, S., and Ağır, H. 2011. Financial Development and Economic Growth Nexus in the MENA Countries: Bootstrap Panel Granger Causality Analysis. Economic Modelling, vol.28, pp. 685-693.

Kenza, M., and Mohamed, B. 2015. Financial development and economic growth in Algeria: An econometric analysis of the transmission channels. EPR A International Journal of Economic and Business Review, vol.3, February.

King, R. G., and Levine, R. 1993. Finance and Growth: Schumpeter might be right. Quarterly Journal of Economics. 108, 717-737

Kumar, R. R. 2011. Do remottances, exports and financial development matter for economic Growth? A case study of Pakistan using bounds approach. Journal of International Academic Research, vol.11. 
Kuznets, S. 1955. Economic growth and income inequality. American Economic Review, vol.45, pp.128.

Levine, R. 2005. Finance and Growth: Theory and Evidence. In Handbook of Economic Growth, ed. P. Aghion and S. N. Durlauf, 865 934. Amsterdam: Elsevier.

Lewis, W. A. 1995. The theory of economic growth. Allen and Unwin, London.

Lonzo, L. G., and Kabwe, O. F. 2015. Intermédiation financière et croissance économique en République Démocratique du Congo. MPRA Paper no. 61261, January.

Lucas, R. 1988. On the Mechanics of Economic Development. Journal of Monetary Economics, vol.22, pp.3-42.

Luintel, K. B. and Khan, M. 1999. A quantitative reassessment of the finance-growth nexus: evidence from a multivariate VAR. Journal of Development Economics, vol.60, pp.381-405.

McKinnon, R. 1973. Money and Capital in Economic Development. Washington, D.C.: Brookings Institution.

Mollaahmetoğlu, E., and Akçalı, B. Y. 2019. The Missing-Link between Financial Development and Economic Growth: Financial Innovation. Procedia Computer Science, vol. 158, pp. 696-704.

Musamali, A. R., Nyamongo, M. E., and Moyi, D. E. 2014. The relationship between financial development and economic growth in Africa. Research in Applied Economics, vol.6, pp.190-208.

Nayak, B., S., and Yingnan, Z. 2019. Critical Reflections on Different Trends in the Relationship between Financial Developments and Economic Growth in China. International Journal of Economics and Finance; vol.11, no.3, https://doi.org/10.5539/ijef.v11n3p89, February.

Nazlıoğlu, S., Ege, I., and Bayrakdaroğlu, A. 2009. Financial Development and Economic Growth: Cointegration and Causality Analysis for Turkey. Banking Finance Letters, vol. 1, pp.59-66.

Ndako, U. B. 2017. Financial development, investment and economic growth: Evidence from Nigeria. Journal of Reviews on Global Economics, vo.6, pp.33-41.

Odhiambo, N. M. 2008. Financial depth, savings, and economic growth in Kenya: A dynamic causal linkage. Economic Modeling, vol.25, pp. 704-713.

Odhiambo, N.M. 2009. Finance-growth-poverty nexus in South Africa: A dynamic causality linkage. The Journal of Socio-Economics, vol.38, pp. 320-325.

Okpara, G. C., and Onoh, A. N., Ogbonna, B. M., et Iheanacho, E. 2018. Econometrics Analysis of Financial Development and Economic Growth: Evidence from Nigeria. Global Journal of Management and Business Research, vol.18.

Olutan, R. 2012. Financial Development and Economic Growth in Africa : Lessons and Prospects. Business and Economic Research, vol. 2, no. 2.

Öztürk, I., and Acaravci, A.2013. The long-run and causal analysis of energy, growth, openness and financial development on carbon emissions in Turkey. Energy Economics, no. 36. pp.262-267. 
Patrick, H.T. 1966. Financial development and economic growth in underdeveloped countries. Economic Development and Cultural Change, vol.14, pp. 174-89.

Pinshi, C. P. 2017a. Boucle rétroactive entre la volatilité des flux de capitaux et la stabilité financière : résultat pour la République démocratique du Congo. HAL Id: bal-01577198, Working paper, August.

Pinshi, C.P. 2017b. A macroprudential perspective on financial stability. Global Journal of Management and Business Research : C Finance, vol.17, pp.27-42.

Pinshi, C.P. 2020. Rethinking Error Correction Model in Macroeconometric analysis: A Relevant Review. Journal of Economics, Finance and Management Studies, vol.3, pp.73-79, May.

Rajan, R. G., and Zingales, L. 1998. Financial Dependence and Growth. American Economic Review, vol.88, pp.559-586.

Robinson, J. 1952. The Generalization of the General Theory and Other Essays. The McMillan Press Ltd, London.

Schumpeter, J. 1911. A Theory of Economic Development. Harvard University Press.

Shan, J., et Jianhong, Q. 2006. Does financial development "lead" economic growth? The case of China. Annals of Economics and Finance, vol.1, pp. 197-216.

Shahbaz, M., et Lean, H.H. 2012. Does financial development increase energy consumption? The role of industrialization and urbanization in Tunisia. Energy Policy, vol.40, pp. 473-479.

Shaw, E. 1973. Financial Deepening in Economic Development. New York: Oxford University Press.

Shittu, A. I. 2012. Financial intermediation and economic growth in Nigeria. British Journal of Arts and Social Science, vol.4, pp.164-179.

Singh, A. 1997. Financial liberalization, stock markets and economic development. The Economic Journal, vol.107.

Soytaş, U., and Küçükkaya, E. 2011. Economic growth and financial development in Turkey: New evidence. Applied Economics Letters, vol.18, pp.595-600.

Spears, A. 1992. The Role of financial intermediation in economic growth in Sub- Saharan Africa. Canadian Journal of Development Studies, vol.13, pp 361-380.

Stern, N. 1989. The economics of development: a survey. The Economic Journal, pp. 597-685.

Wood, A. 1993. Financial development and economic growth in Barbados: causal evidence. Savings and Development, vol.17, pp.379-380. 